\title{
Anadolu Geleneksel Kırsal Mimarisinde Düz Toprak Damların İyileştirilmesine Yönelik Öneriler
}

\author{
Ülger BULUT KARACA ${ }^{1}$
}

Öz

Tarihsel ve kültürel belleğin bir parçası olan geleneksel kırsal mimari örnekleri fiziksel eskime sonucunda yok olmaktadır. Tüketim kültürü ile değişen günümüz yaşam koşullarında geleneksel kırsal mimari yetersiz bulunmakta ve bunun sonucunda geleneksel kırsal mimari üretimi kısıtlı kalmaktadır. Düz toprak dam uygulanan geleneksel kırsal mimari örneklerinde sürekli ve yoğun emek isteyen bakım gereksinimleri nedenleriyle ilk vazgeçilen/değiştirilen yapı elemanının toprak damlar olduğu söylenebilir.

Düz toprak damların tarihi Anadolu'da neolitik dönemlere kadar uzanmaktadır. Geleneksel kırsal mimari belleğin yitmemesi için, düz toprak dam uygulamalarındaki bu bakım gereksinimlerinin öz nitelikler bozulmadan, güncel teknolojilere dayalı çözümler ile iyileştirilmesi gerekliliği ortaya çıkmaktadır. Bu çalışma ile Anadolu geleneksel kırsal mimarisinin karakteristik unsurlarından düz toprak damların güncel bilgi ve teknolojiler ile iyileştirilerek uygulanmaları için öneride bulunularak daha az bakım gerektiren detay çözümleri sunulmaktadır.

Bu amaçla, çalışmada yöntem olarak öncelikle kırsal mimaride yapı malzemesi olarak toprak ele alınmış, ardından düz toprak damın tarihi incelenmiştir. Düz toprak damın temel sorunları ele alınmış ve çözüm önerisi sunulmuştur. Öneri olarak sunulan düz toprak dam ve geleneksel düz toprak dam uygulamalarının enerji etkinliklerinin karşılaştırılması amacıyla modellemesi yapılmıştır. Simülasyon sonucunda güncel malzeme ve teknolojiler kullanılarak üretilen öneri düz toprak dam kesitinin ısıtma ve soğutma enerji gereksinimlerini azalttığı belirlenmiştir.

Çalışma kapsamında belirlenen düz toprak damların yapı fiziği ve durabilite sorunları bu çalışmanın bulguları olarak değerlendirilmiştir. Bu çalışmanın, düz toprak damların yapı fiziği sorunlarının azaltılması ve daha az bakım gerektirmesi için güncel olanaklar ile iyileştirilerek yaşatılmasına sosyal katkı sunacağı düşünülmüştür.

Anahtar Kelimeler: Geleneksel kırsal mimari, Düz toprak damlar, Sürdürülebilirlik

\section{Suggestions for the Improvement of Soil-Covered Flat Roofs in Anatolian Traditional Rural Architecture}

\begin{abstract}
\footnotetext{
${ }^{1}$ İstanbul AREL Üniversitesi, Mühendislik-Mimarlık Fakültesi

* İlgili yazar/Corresponding author: ulgerbulut@hotmail.com

Gönderim Tarihi / Received Date: 13.02.2021

Kabul Tarihi / Accepted Date: 03.08.2021
}

Traditional rural architecture examples, which are a part of historical and cultural memory, disappear as a result of physical aging. In today's living conditions that change with the consumption culture, traditional rural architecture is insufficient and as 
a result, traditional rural architectural production remains limited. In traditional rural architectural examples with soil-covered flat roofs, it can be said that soil-covered flat roofs are the first to be abandoned / replaced due to constant and demanding maintenance requirements.

The history of soil-covered flat roofs goes back to the Neolithic times in Anatolia. In order not to lose the traditional rural architectural memory, it is necessary to improve these maintenance requirements in soil-covered flat roof applications with solutions based on current technologies without deteriorating their attributes. In this study, detailed solutions requiring less maintenance are offered by making suggestions for the implementation of soil-covered flat roofs, one of the characteristic elements of Anatolian traditional rural architecture, by improving them with up-to-date knowledge and technologies.

For this purpose, as a method in the study, firstly earth was considered as a building material in rural architecture and then the history of the soil-covered flat roof was examined. The basic problems of the soil-covered flat roofs are discussed and solution suggestion is presented. Modeling of the proposed soil-covered flat roof and conventional soil-covered flat roof implementations were carried out in order to compare their energy efficiency. As a result of the simulation, it was determined that the proposal produced using up-to-date materials and technologies reduces the heating and cooling energy requirements of the soil-covered flat roof section.

The building physics and durability problems of the soil-covered flat roofs determined within the scope of the study are evaluated as the findings of this study. It is thought that this study will contribute socially to the improvement of soil-covered flat roofs with up-to-date possibilities in order to reduce the building physics problems and require less maintenance.

Keywords: Traditional rural architecture, Soil-covered flat roof, Sustainability

\section{Giriş}

"Geleneksel mimari geniş anlamıyla uzman mimarların müdahalesi olmaksızın tecrübe ve deneyime dayalı bilgiyle inşa edilmiş yapılardır" (Muşkara, 2017; s. 439). "Dünya Vernaküler Mimarlık Ansiklopedisi'nin tanımına göre ise kırsal mimarlık; halk tarafından yapılmış tüm evler ve diğer yapıları kapsar. Seçilen çevrenin olanakları ve elde var olan malzemelerle, çoğunlukla konut sahibi ya da yerel yapı ustaları tarafından geleneksel tekniklerle inşa edilmiştir." (Çekül, 2012, s. 5; Muşkara, 2017, s. 439 ).

İklim, coğrafya, ekonomik altyapı ve kültürel üstyapı geleneksel kırsal mimari kimliğin oluşumunda etkili faktörler olarak sıralanabilir. Geleneksel kırsal mimari, bu faktörlerin bileşkesi olarak ortaya çıkar. Geleneksel kırsal mimaride, fiziksel ortamın iklimsel ve coğrafi koşullarına uygun, mevcut olanaklardan en çok faydayı hedefleyen mimari çözümler hedeflenir. Geleneksel kırsal mimarinin yapım ve kullanım süreçlerinde karşılaşılan sorunlar deneyim yoluyla çözülür. $\mathrm{Bu}$ çözümlerin başarısının değerlendirilmesinde yapının kullanım ömrü ve yapım tekniğinin sürekliliği ölçüt kabul edilebilir. Geleneksel kırsal mimarinin üretiminde karşılaşılan sorunlar ve bu sorunların çözümlerinde kullanılan yapı malzemeleri, yapım teknikleri, mimari öğeler geleneksel kırsal mimariye özgünlük kazandırır.

“...çok farklı coğrafi özellikleri olan, bunun yanı sıra tarihin derinliklerinden beri göç almış göç vermiş, özellikle son 200 yılda çok büyük kitlesel göç hareketleri yaşamış 
olan Türkiye coğrafyasının kırsal mimarlık kültürü de en az arkeolojisi, anıt eserleri, varlıklı kent mimarlığı kadar zengindir, çeşitlidir" (Eres, 2016, s. 8). Ancak, Anadolu'da 1950'li yıllardan itibaren hızlı kentleşmeden dolayı kentlere doğru büyük insan hareketliliği ile genç nüfus kırsal alanı terk etmiş, tarım ve hayvancılık ekonomisi zayıflamış, geleneksel kırsal mimari bakımsız kalarak yıkılmaya, yok olmaya başlamıştır. Ekonomik canlılığı süren kırsal yerleşimler ise, 1980 sonrası çağdaş yapı malzemelerinin daha ulaşılabilir ve uygun fiyatlı hale gelmesi sonucunda değişmeye başlamıştır. Bir diğer yandan hızlı sanayileşme ve buna paralel gelişen tüketim kültürü ile yaşam koşulları değişerek geleneksel kırsal mimarinin yetersiz kalmasına neden olmuştur.

Tarihi ve kültürel kimliği olan geleneksel kırsal mimarinin çağdaş yaşam koşullarına uygun olarak varlığını sürdürebilmesi gereklidir. "Kırsal mimarinin korunması gerekli bir değer olduğu özellikle on dokuzuncu yüzyılın ikinci yarısından sonra Avrupa'da çıkarılan yasa ya da tavsiyelerle desteklenmiştir" (Çağlayan, 2018, s. 273). Buna paralel olarak, "Türkiye mimarlık kültürünün önemli bir bileşeni olan geleneksel kırsal yerleşimler, son yıllarda koruma biliminin konularından biri olmaya başlamıştır" (Eres, 2016, s. 8). Geleneksel kırsal mimarlık örneklerinin günümüz teknik olanakları ile yenilenerek yaşatılması ve hukuki güvencelere sahip bütünlüklü koruma programlarının hazırlanıp uygulanması gereklidir.

Düz toprak dam uygulanan geleneksel kırsal mimari örneklerinde sürekli ve yoğun emek isteyen bakım gereksinimleri nedenleriyle ilk vazgeçilen/değiştirilen yapı elemanının toprak damlar olduğu söylenebilir. Büyükmıhçı ve arkadaşları (2015, s. 164), Kayseri ili Germir Mahallesi'nde yaptıkları incelemeler sonucunda bakım sorunları ve kullanım zorlukları nedeniyle geleneksel düz toprak damların üzerine beton dökülerek orijinali dışında bir kesite dönüştürüldüğüne sıklıkla rastlandığını belirlemişlerdir. Her yağmur ve özellikle kar yağışından sonra sıkıştırılması suretiyle bakım gerektiren, deprem yönünden önemli sakınca yaratan toprak damlar, geçmişte uygulandıkları coğrafyalarda günümüz kırsal mimari yapıları için tercih edilmemektedir. "Geleneksel mimarlık ögelerinin sürekli ve yoğun emek isteyen bakım gereksinimleri, mimari kimliğe dair öz nitelikler bozulmadan, güncel teknolojilere dayalı çözümler ile ortadan kaldırılmalıdır" (Bulut Karaca ve Şimşek, 2020, s. 44).

Bu bağlamda çalışmanın amacı;

- Geleneksel kırsal mimarinin özgün bir bileşeni olan düz toprak damlar için güncel teknolojilere dayalı ve daha az bakım gerektiren bir çatı kesiti önerisinde bulunmak;

- Geleneksel düz toprak dam ve öneri düz toprak dam kesitlerini enerji verimliliği açısından karşılaştırmak;

- Bu konuda bir farkındalık oluşturmak ve gelecekte yapılacak araştırmalara zemin oluşturmaktır.

Geleneksel kırsal mimarlık örneklerinin günümüz teknik olanakları ile yenilenerek yaşatılması amacıyla önerilen çatı kesitinin;

- Geleneksel kırsal mimarinin sürekliliğine katkı sağlayacağı;

- Düz toprak damın, geleneksel uygulamalara kıyasla daha az bakım gerektireceği ve kullanıcı memnuniyeti sağlayacağı varsayılmaktadır. 


\section{Yöntem}

Bu çalışmada, öncelikle kırsal mimaride toprak yapı malzemesi ele alınmış; ardından düz toprak damın tarihsel gelişimi incelenmiştir. Yapı fiziği ve malzeme açısından düz toprak dam uygulamaları değerlendirilmiş; standartlar ve yasal düzenlemeler araştırılmıştır. Düz toprak damların daha az bakım gerektirmesi, durabilitesinin iyileştirilmesi ve zafiyetlerinin azaltılmasına yönelik bir öneri düz toprak dam kesiti geliştirilmiştir. Geleneksel toprak dam ve öneri düz toprak dam kesitleri basit bir plan şeması ile EnergyPlus ve Designbuilder programları kullanılarak Bitlis ili iklim koşulları için modellenmiş; yaz ve kış mevsimlerinde ısıl kayıp ve kazançları hesaplanmıştır.

\section{Kırsal Mimaride Toprak Yapı Malzemesi}

İnsanların yerleşik düzene geçmelerinden bu yana toprak yapı malzemesi olarak kullanılmaktadır. "Toprak yapı kavramı, pişirilmeden oluşan toprak kökenli tüm yapı türlerini ve bileşenlerini kapsar" (Kafesçioğlu, 2017, s. 4). Toprak, çıkarıldığı yere bağlı olarak, farklı miktarlarda ve tipte kil, silt, kum ve agregalardan oluşması nedeniyle standart özellikte bir yapı malzemesi değildir. Yapı toprağının içeriği dane boyutuna göre sınıflandırıldığında,

- $\quad 0,002$ mm'den küçük çaplı parçacıklar "kil",

- 0,002 ile 0,06 mm arasında olanlara "silt",

- 0,06 ile $2 \mathrm{~mm}$ arasında olanlara "kum",

- Daha büyük çaplı parçacıklar çakıl ve taş adını alır.

Kil, yapı toprağında bağlayıcı görevi görür; silt, kum ve agregalar ise dolgu maddelerini oluşturur.

Kil, feldspat ve diğer minerallerin aşınmasının bir ürünüdür. En yaygın feldspat türlerinden biri $\mathrm{Al}_{2} \mathrm{O}_{3} \cdot \mathrm{K}_{2} \mathrm{O} \cdot 6 \mathrm{SiO}_{2}$ kimyasal formülüne sahiptir. Diğer bir yaygın kil türleri kaolinit, montmorillonit, illit, bentonit, allofen ve imogolit olarak sayılabilir.

Kil, küçük gözeneklere sahip olduğu için killi toprak içinde su ve havanın hareketi güçleşir. Topraktaki kil miktarının düzeyi, toprağın sıkışma özelliği üzerine doğrudan etkilidir. Bu nedenle killi toprak su geçirimsizdir, ISI iletimi düşüktür ve kohezyon niteliğine sahiptir.

Toprağın yapı malzemesi olarak işlenebilmesi ve şekil verilebilmesi için kullanılan suyun buharlaşması sonucunda toprak yapı malzemesinde rötre (büzülme) çatlakları oluşabilir. Bu duruma karşı toprakta kil ve su içeriği azaltılarak, tane boyutu dağılımı optimize edilerek ve "çorak" ya da "trim" denilen tuz içeriği yüksek özel killi toprak katkı maddeleri kullanılarak rötre çatlakları azaltılır.

Toprak havadaki nemi dengeler; nemi diğer tüm yapı malzemelerinden daha hızlı ve daha büyük ölçüde absorbe ve desorbe ederek iç ortam ikliminin dengelemesini sağlar. "Bir odadaki bağıl nem aniden \% 50'den \% 80'e yükseldiğinde, iki günlük bir dönemde pişmemiş toprak tuğlaların pişmiş tuğlalara göre 30 kat daha fazla nem emebildiği belirlenmiştir" (Minke, 2009, s. 14).

"Sudan sonra en iyi enerji depolayan malzeme olan toprak, Isınma enerjisini bünyesinde depolar. Isıtma kesildikten sonra uzun bir süre depoladığı enerjiyi mekâna vererek sıcaklığı dengeler. Yapı içerisinde oluşan buharın duvardan rahatlıkla geçmesi nedeniyle dış duvarlarda ve tavanlarda yoğuşma oluşmaz" (Koçu, 2012, s. 6). Günlük sıcaklık farklarının yüksek olduğu iklim bölgelerinde veya pasif yollarla güneş ısısı 
kazanımının depolanmasının gerekli olduğu yerlerde, toprak iç ortam iklimini dengeleyebilir. Bu özellikleri nedeniyle toprak malzeme Anadolu geleneksel kırsal mimarisinde duvar, döşeme ve çatı için yaygın olarak kullanılmıştır.

"Toprak yapı malzemesinin sahada hazırlanması, taşınması ve işlenmesi süreçlerinde gereken enerji, Pişmiş tuğlaların veya betonarme betonun üretimi, taşınması ve işlenmesi için gereken enerjinin \% 1'i kadardır" (Minke, 2009, s. 14). Bu nedenle Toprak yapı malzemesinin, neredeyse hiç çevre kirliliği üretmediği, enerji tasarrufu sağladığı ve çevre kirliliğini azalttığı söylenebilir.

Toprak yapı malzemesi her zaman yeniden kullanılabilir; çok uzun bir süre boyunca sınırsız sayıda geri dönüştürülebilir; çevreye zarar veren atık bir malzeme haline gelmez.

Geleneksel kırsal mimaride yapı malzemelerinin doğadan sağlanması bir tahribat yaratsa bile, yapının nesilden nesile kullanılması ve bunun sonucunda yeni konut yapımına olan ihtiyacın azalması, doğanın kendisini yenilemesine olanak tanır. Özellikle son yıllarda ekolojik mimari gibi akımların ilgi görmesiyle birlikte, kırsal mimari ve toprak yapılar yeniden gündeme gelmiş; 2010 yılında tamamlanan Konya- Hüyük'te Sonsuz Şükran Köyü ve 2012'de tamamlanan Şanlıurfa- Viranşehir'de Toprak ve Su Kollektifi Evleri gibi projeler ile yeniden uygulanma fırsatı bulmuştur.

“Toprak yapılar ilk çağlardan günümüze kadar insanlar tarafından tercih edilmiş, üretilmiş ve farklı amaçlarla kullanılmıştır. Bu kapsamda; Dökme Toprak Tekniği, Hafif Toprak Tekniği, Sıkıştırılmış Toprak Tuğla Tekniği, Kerpiç Tekniği, Yerinde Dökme Toprak Tekniği, Omurgalı Kerpiç Tekniği ve Sıkıştırılmış Toprak Tekniği gibi farklı toprak yapı üretim teknikleri bulunmaktadır" (Koç ve Ekşi Akbulut, 2017, s. 651). Anadolu'da toprak yapılar genellikle kerpiç bloklar ile yığma yapı veya ahşap iskeletli kerpiç dolgu (hımış) yöntemleri ile yapılmıştır. Bu binaların üst örtüleri eğimli çatı olabildiği gibi sıkıştırılma yöntemiyle üretilen düz toprak dam ya da kerpiç bloklardan oluşan kubbe olabilmektedir. Bu çalışmaya konu olan düz toprak damlar, ahşabın kolay temin edilemediği, İç Anadolu gibi az yağışı ve gece-gündüz / yaz-kış ısıl farkların yüksek olduğu bölgelerde yaygındır.

Toprak esaslı duvar bloğu, dam ya da harç gibi yapıdaki farklı kullanımına göre farklı nitelik ve hazırlanma süreci gerektirir. "Genel olarak duvar yapımında kullanılan topraklar düz çatı oluşumlarında kullanılabilseler de, her duvar yapımında kullanılacak toprak bu amaç için uygun olmayabilir, çünkü düz toprak çatılarda toprağın su sızdırmazlık bakımından tane dağılımına ve sıkıştııılabilirliğine dikkat etmek gerekir" (Çiçek, 2014, s. 6).

Anadolu toprak yapılar ile ilgili köklü bir yapı geleneği ve deneyimine sahip olsa da, ne yazık ki günümüzde Türkiye'de toprak yapı üretiminde kullanılan yönetmelik ve standartlar kısıtlıdır. Bu standart ve yönetmelikler TS 2514 (Kerpiç Bloklar ve Yapım Kuralları), TS 2515 (Kerpiç Yapıların Yapım Kuralları), Deprem Yönetmeliği: Yığma Binalar için Depreme Dayanıklı Tasarım Kuralları olarak sayılabilir. Bu sayılanlardan TSE 2514 ve TSE 2515, 2011 yılında yürürlükten kaldırılmış ve yenilenmemiştir. "Deprem Yönetmeliği'nde yer alan bazı maddeler toprak yapı üretimini kısıtlamaktadır. $\mathrm{Bu}$ nedenle, toprak yapılar Türkiye coğrafyasına ve iklim şartlarına uygun olmasına rağmen sınırlı düzeyde kalmaktadır" (Koç ve Ekşi Akbulut, 2017, s. 652). Dolayısıyla, Türkiye'de farklı toprak yapı üretim tekniklerini içeren, kapsamlı yasal düzenleme ve standartlara gereksinim olduğu söylenebilir. 


\section{Düz Toprak Dam}

Tarihsel olarak toprak malzemenin yapıda kullanımı, insanların barınma gereksinimi ile gelişip şekillenmiştir. Özdoğan (2005, s. 149)'a göre günümüzden 14000 yıl kadar önce, neolitik dönemde "barınak"ın "konut"a dönüşmesiyle birlikte yapı planlaması, yapım teknikleri, yapı malzemesi ve yerleşme düzeni de değişerek günümüze kadar gelen köy mimarisinin temelleri oluşmuştur. Anadolu'da neolitik dönemine dair Çayönü (Diyarbakır) kazılarında, "dallardan örülmüş yuvarlak planlı basit bir kulübenin, dörtgen planlı, taş temel üzerine kerpiç tuğla duvarlı, düz damlı, bodrumlu, kapısı ve penceresi olan bir yapıya nasıl dönüştüğü, mimarlıkta çözümlerin deneme-yanılma yöntemiyle nasıl bulunduğu açık olarak izlenmektedir" (Özdoğan, 1996, s. 24-25). Yuvarlak plan şemalı yapılarda duvar ve çatı ayrışmamış; ağaç dalı ve kamış gibi malzemelerden oluşturulan bir sepet örgünün çamur ile sıvanması ile yapı kabuğu oluşturulmuştur (Şekil-1). Dörtgen plan şemasının gelişmesi ile birlikte duvar yükseklikleri artmış ve düz dam ortaya çıkmıştır. "Barınak"ın konuta dönüşmesi süreci, deneme-yanılma yoluyla zaman içinde gelişerek M.Ö. 6000 yıllarında son şeklini almış ve o tarihten sonra hemen hemen hiç değişmeden günümüze kadar gelmiştir (Şekil-2).

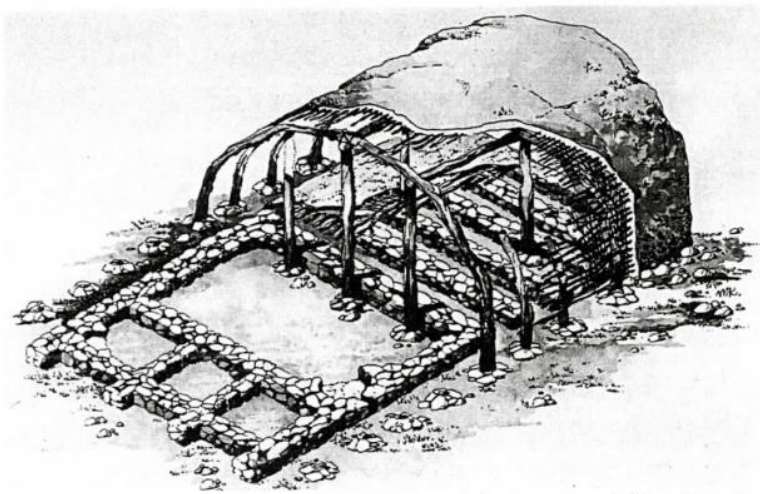

Şekil-1: Çayönü; dörtgen planlı en eski yapı türü olan ızgara planlı yapıların, hafif malzemelerden olan üst örtü tamamlaması taslak çizimi

(Özdoğan, 2005, s. 149)

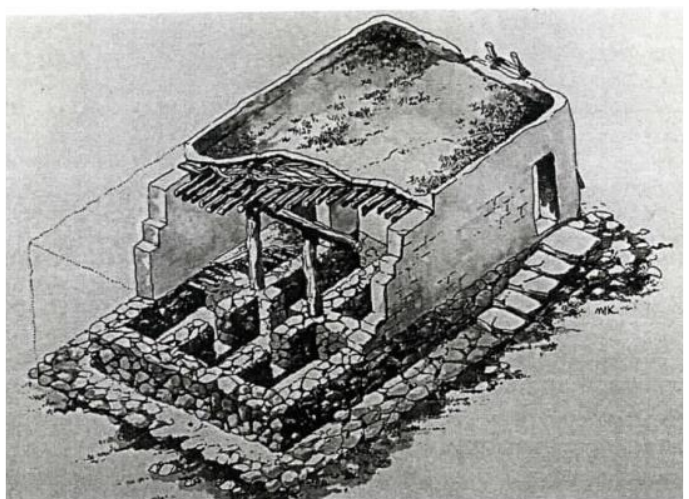

Şekil-2: Çayönü; taş temel üstüne kerpiç duvar ve düz damlı ilk yapılar; hücre planlı yapının canlandırma resmi (Özdoğan, 2005, s. 150)

20. yüzyıl Anadolu geleneksel kırsal mimarisinde düz toprak damın Karadeniz ve kısmen Marmara bölgeleri haricinde uygulandığı söylenebilir. Anadolu'da düz toprak damın tercih edilmediği bölgelerde yaz-kış sıcaklık farkı düşük, yıllık yağmur yağışı oranının yüksektir. Muhtemelen yağışların yüksekliği, gerek erozyon gerekse su yalıtımı sorunlarının düz toprak dam sistemi dahlinde giderilebilmesini engellemiştir. Yaz mevsimi oldukça sıcak geçen Akdeniz-Ege şeridinde düz toprak damın, iç mekânları serin tutma aracı olarak tercih edildiği söylenebilir.

Anadolu'da yaz ve kış mevsimleri sıcaklık farkının yüksek olduğu karasal iklim bölgelerindeki geleneksel kırsal mimaride toprak yapılar önemli yer tutmuştur. Bu bölgelerde kış mevsiminin uzun ve kar yağışlı geçmesi nedeniyle düz toprak dam üzerine biriken kar yığınlarını temizleme, bitkilerin kök salmasını ve toprağın gevşemesini önleme zorunluluğu yoğun bir işgücünü gerektirir. Buna rağmen Bitlis, Erzurum, Kayseri ve Sivas gibi kış etkisinin ve dolayısıyla kar yağışının etkili olduğu kentlerin kırsal yerleşimlerinde düz toprak dam uygulamalarından vazgeçilmemiştir. Bu bölgelerde düz toprak damın hayvan barınağı, depo, okul ve ibadethane gibi konut dışındaki yapılarda da uygulandığı görülmektedir. 
Düz toprak damların yapımında yerel farklılıklar görülse de, genel ilkeleri ile düz toprak dam kurgusu özetlenebilir (Şekil-3-4): damın örteceği mekanın duvarları üstüne, plan şemasının kısa kenarına paralel olacak şekilde ahşap kirişler yerleştirilir. Bu ahşap kirişler, uzun ve hafif olmaları nedeniyle $15-25 \mathrm{~cm}$ çapında tomruk haldeki kavak veya söğüt ağacından yapılır. Bu kirişlerin aralıkları geçtikleri açıklara ve merteğin büyüklüğüne göre değişmekle birlikte $40-60 \mathrm{~cm}$. civarındadır. Bu kirişler, taşıyıcı haldeki duvarların üzerinde yer alan "taban ağacı" denilen son hatıla oturur. Kirişlerin üstüne, ahşap kirişler ile yatay eksenle $90^{\circ}$ açı ile kamış hasır, çalı ya da ağaç dalı yerleştirilir. Bu katmanın üzerine ise kalınlığı $10-30 \mathrm{~cm}$ arasında değişen toprak katmanı serilir. Toprak katmanının güneş, yağmur ve diğer etkilerden korumak amacıyla üzerine ince bir katman halinde taş kırığı yerleştirilir; ya da 3-4 cm civarında su geçirimsiz kil ve tuz oranı yüksek, "çorak" denilen toprak serilir. Ardından "loğ taşı" ya da "yuvak taşı" denilen silindir şeklindeki ağır taş ile sıkılaştırma yapılır.

Düz toprak damın su ile teması sonucunda, yağış suyu rötre çatlaklarına girdiğinde toprağın içindeki kil şişer ve rötre çatlaklarını kapatır. Higroskopik olması nedeniyle çorak katmanı, daha uzun süre nemli kalır ve bu durumda kalırken su girişini engeller. Çorak katmanı bentonit killerinden olup, "suyla temasa geçtiğinde hacminin 2-10 katı su emerek şişer; kuruduktan sonra bu suyu geri vererek büzülür ve hacmini küçültür" (Akbulut,1995, s.53). Yağış, çorak katmanının tuzunu azalttığında, dam yüzeyine tuz serpilebilir ya da üzerine tuzlu su dökerek yalıtım yeniden oluşturulabilir. Çorak katmanın üzerine beyaz çakıl serilerek güneş etkisinden korunabilir.

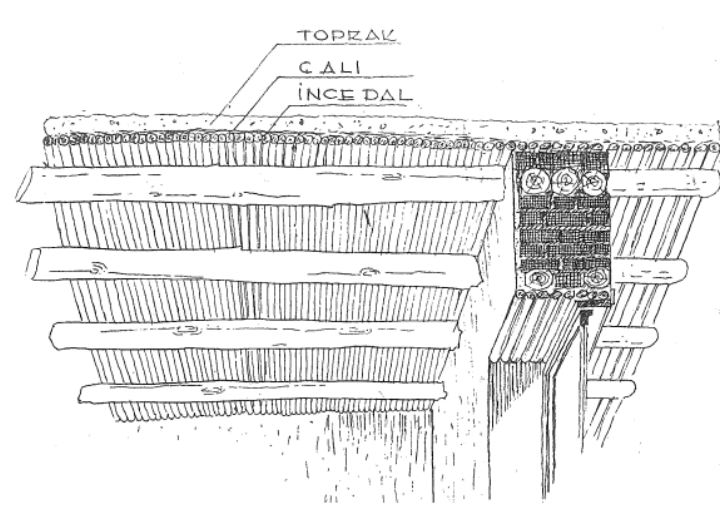

Şekil-3: Kayseri çevresinde bir köy evinin tavan kirişleri ve toprak damı (Kafesçioğlu, 1949, s. 52)

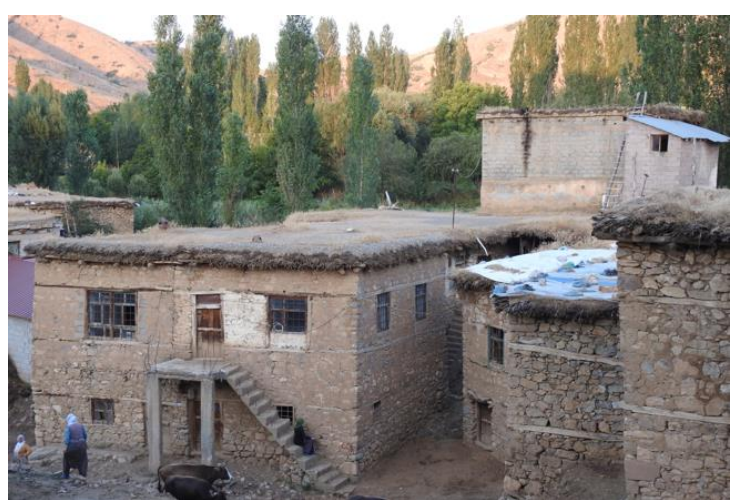

Şekil-4: Bitlis Yolalan Köyü'nden düz toprak damlı evler (Ergün Şimşek'in kişisel arşivi, 2019)

Geleneksel yapılar düzenli zaman aralıkları ile bakım ve onarım gerektirir. Üstelik bu iş oldukça zahmetli ve uzun zaman alan bir faaliyettir: Kış mevsiminde kar yüküne maruz kalmaması, ilkbaharda toprak dam yüzeyinde bitki filizlenmemesi, sonbaharda olası yağmur sızıntılarını önlenmesi için düz toprak dam sürekli emek yoğun bakım gerektirir. Ayrıca, afet durumlarında düz toprak damın zarar görme riskinin diğer geleneksel yapım yöntemlerine göre yüksek olduğu söylenebilir.

Düz Toprak damlar bir yapı elemanı olmanın dışında, oluşturduğu mekan ve kültür ilişkisi üzerinden işlevler de yerine getirir. Reyhanoğlu ve Yavuz (2020, s. 1124)'a göre Kilis, Şanlıurfa, Mardin, Adana, Gaziantep ve Hatay'da olduğu gibi Anadolu'da damın aktif olarak, işlevsel bir sosyal alan olarak kullanıldığı yerlerden biridir. Günümüze değin ulaşan düz toprak damların mekan olduğu mevsimlik ve gündelik işlevler: yaz mevsiminde damda uyuma, misafir ağırlama, yiyecek kurutma ve benzeri imece usulü yapılan işler şeklinde özetlenebilir. 
Endüstriyelleşme ve beraberinde kırsal nüfusun endüstriyel alanlara ve kentlere göç etmesi, Türkiye'de 1960'lı yıllarla birlikte büyük bir ivme kazanmıştır. Bunun sonucunda, yaşamın görenekler ile sürdürüldüğü kırsalda yerli nüfus azalmış, boş kalan binalar yıkılmaya terk edilmiştir. Nüfusun seyrekleşmesiyle birlikte sivil mimarlığın yaklaşık 7000 yıllık birikimini yansıtan yapıların üretimi de günden güne azalmıştır.

Diğer yandan, düz toprak damların bakım zorluğunun yanı sıra endüstriyel malzeme ve modern teknolojilerin avantajlarından yararlanma arzusu nedenleriyle son yıllarda Anadolu'da, düz toprak damın kaldırılıp yerine bakımı daha kolay çatı sistemlerinin uygulanması yaygınlaşmıştır. Sonuçta geleneksel mimari tasarım ilkeleri bakımından ne derece başarılı olursa olsun, popüler kültürden beslenen motivasyonlar bu tasarım ilkelerini etkilemekte, değiştirmektedir. Ayrıca, hiç kimse geçerliliğini yitirmiş bir çağın yaşam alışkanlığını sürdürmeye de zorlanamaz. Bu gerçeklik, geleneksel kırsal mimarlığın çağdaş yaşam koşullarına uygun varlığını sürdürebilmesi için kimliği ile uyumlu çağdaş tasarımların gerekliliğini ortaya çıkmaktadır.

Sonuçta, fiziksel eskimeye uğrayan geleneksel kırsal mimari örneklerinin sayısındaki artışın yanı sıra, bu türden yapıların üretiminin de az olması tarihsel ve kültürel bellek yitimi olarak kabul edilebilir.

\section{Bulgular}

Geleneksel yapım tekniği ve vernaküler malzemeler ile üretilen düz toprak damın bakım zorluğu, yapı fiziği ve eskime kaynaklı sorunları güncel malzeme ve teknikler kullanılarak aşılabilir; düz toprak damın durabilitesi artırılabilir.

Yağış suyunun çatı yüzeyinden cepheye akması ve duvar kesitine nüfuz etmesi, taşıyıcı olan duvar için zararlı olabilmektedir. Düz toprak dam uygulamalarında yaygın olarak, yağış suyunun yüzeyden uzaklaştırılması için bir düzenek bulunmamaktadır. Düz toprak dam yüzeyinde yağış suyunun tahliyesini kolaylaştırmak için, dam yüzeyinde \% 2-5 gibi bir oranda eğim verilebilmesi yararlı olur. Bunun için toprak katmanı ile ahşap kirişler arasındaki dal ve saz gibi malzemelerden oluşan dolgu, geçtiği açıklığın ortasında kalınlaştıılarak bu eğim sağlanabilir. Çatı parapetinin içine yerleştirilen ahşap ya da taş çörten, düz toprak dam çözümlerinde yağmur suyunun tahliyesi için yararlı olur (Şekil-5).

Geleneksel düz toprak dam uygulamalarında kavak ya da söğüt ağacı tomruklarından yapılan kirişlerde, su nedeniyle çürüme, aşırı yüklenme nedeniyle sehim yapma gibi deformasyonlar görülebilir; bu tür durumlarda toprak katmanı kaldırılarak kiriş değiştirilmesi gereklidir. Damı taşıyan ahşap kirişlerin deformasyon nedeniyle değiştirilmesi için tüm katmanların kaldırılması gerekir. Bunun yerine bir plak halinde düz damın kriko yardımıyla kaldırılarak merteğin değiştirilmesi daha kolay bir çözüm olur. Ayrıca, kirişlerin lamine elemanlar ile yapılması hem eğilme ve basınç mukavemetlerini artıracak hem de su sızması durumunda çürüme, sehim yapma gibi deformasyonları önler.

Düz toprak dam kurgusunda toprak katmanı ile ahşap kirişler arasında yeralan saz ve dalların yerine $2 \mathrm{~cm}$ kalınlıkta su kontrplağı kullanılabilir. Su kontrplağı üzerine plastik veya bitüm kökenli 1-2 kat membran serilmesi ile en dış katman olan sıkıştırılmış toprağın su geçirimsizlik artırılabilir. Su geçirimsizlik membranının üzerine drenaj levhası ve drenaj levhasının toprak ile dolmaması için elyaf keçe yerleştirildikten sonra hidrolik kireç ve kil katkılı sıkıştırılmış toprak serilebilir. (Şekil -5). 


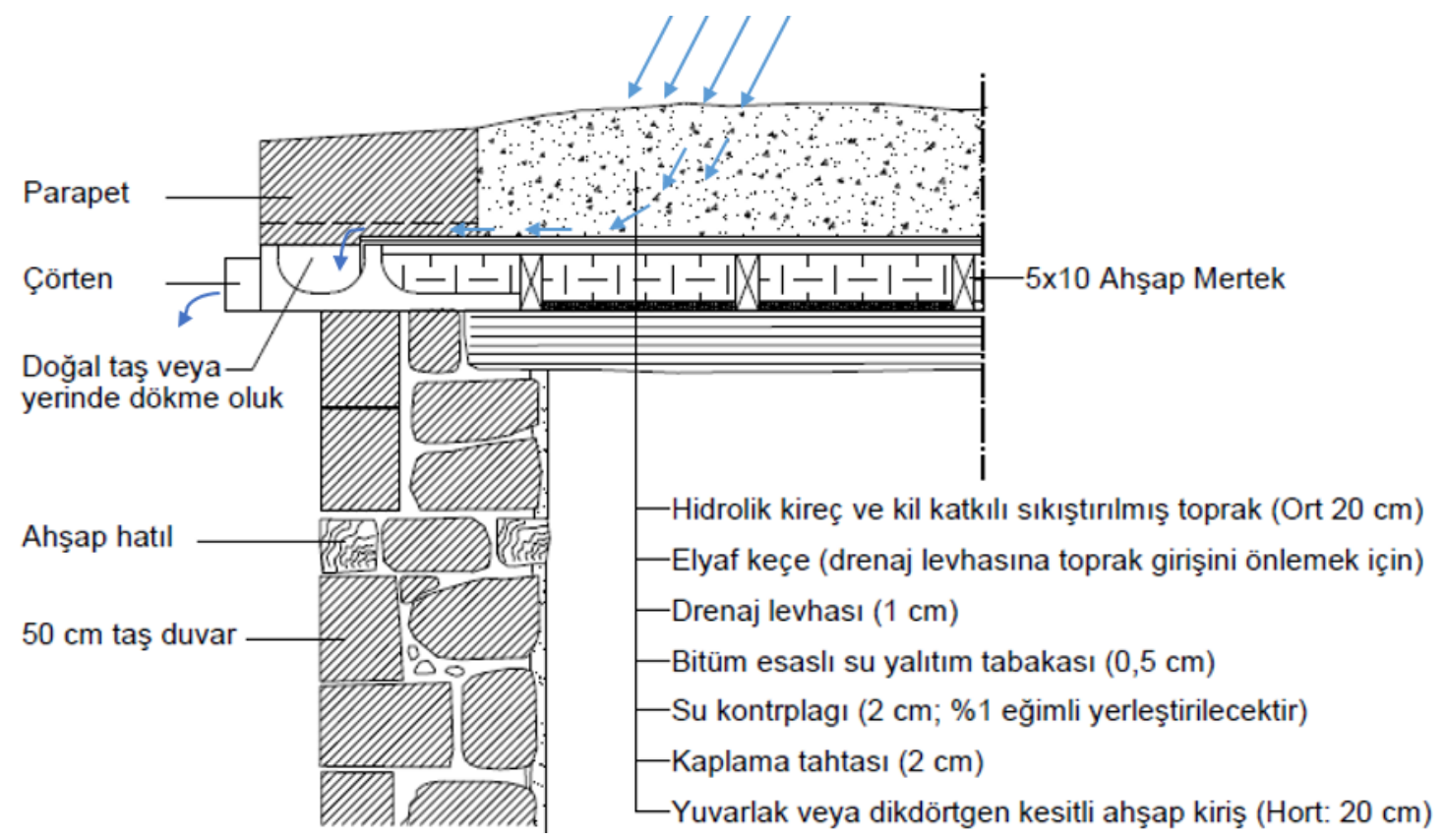

Şekil-5: Çörten ve yalıtım katmanları uyarlanarak önerilen düz toprak dam kesiti (Yazar tarafından hazırlanmıştır.)

\subsection{Geleneksel ve önerilen düz toprak damların modellenmesi ve enerji etkinliklerinin karşılaştırılması}

Çalışma kapsamında önerilen düz dam kesitinin ve geleneksel düz dam kesitinin enerji tüketim miktarlarına göre kıyaslanması amacıyla "EnergyPlus" ve "DesignBuilder" bina enerji simülasyon programları kullanılarak, Bitlis ili iklim koşullarında tek katı basit plan şemalı bir bina modellenmiştir. "DesignBuilder yapı tasarımlarını enerji, karbon, aydınlatma ve konfor açılarından performans ölçmek ve kontrol etmek için geliştirilmiş EnergyPlus tabanlı bir yazılım aracıdır" (URL-1).

Geleneksel düz dam ve önerilen düz toprak dam kesitlerinin enerji verimliliklerinin kıyaslanması amacıyla $400 \mathrm{~cm} \times 300 \mathrm{~cm}$ en ve boy ölçülerinde, $300 \mathrm{~cm}$ kat yüksekliğinde bir model oluşturulmuş; bu modellerde zemin döşeme katmanları ve duvar katmanları aynı olup, dam katmanlarında farklılıklar tanımlanmıştır (Tablo-1).

Tablo-1: Simülasyon için modellenen geleneksel düz toprak dam ve önerilen düz toprak dam-

\begin{tabular}{|c|c|c|c|}
\hline & Dam katmanları & Zemin döşeme katmanları & Duvar katmanları \\
\hline $\begin{array}{l}\text { Geleneksel } \\
\text { Düz Toprak } \\
\text { Dam }\end{array}$ & $\begin{array}{l}\text { Çorak }(4 \mathrm{~cm}) \\
\text { Sıkıştırılmış toprak }(20 \mathrm{~cm}) \\
\text { Çalı/ kamış hasır }(10 \mathrm{~cm})\end{array}$ & & \\
\hline $\begin{array}{l}\text { Önerilen Düz } \\
\text { Toprak Dam }\end{array}$ & $\begin{array}{l}\text { Sıkıştırılmış toprak }(20 \mathrm{~cm}) \\
\text { Elyaf keçe }(1 \mathrm{~cm}) \\
\text { Drenaj levhası }(1 \mathrm{~cm}) \\
\text { Bitüm esaslı su yalıtımı }(1 \mathrm{~cm}) \\
\text { Su kontrplağı }(2 \mathrm{~cm}) \\
\text { Cam yünü ısı yalıtım levhası }(10 \\
\mathrm{cm}) \\
\text { Kaplama tahtası }(2 \mathrm{~cm})\end{array}$ & $\begin{array}{l}\text { Kaya zemin }(50 \mathrm{~cm}) \\
\text { Taş zemin }(25 \mathrm{~cm})\end{array}$ & $\begin{array}{l}\text { Kireç sıva }(5 \mathrm{~cm}) \\
\text { Taş }(50 \mathrm{~cm}) \\
\text { Alçı }(5 \mathrm{~cm}) \\
\text { Kıtıklı sıva }(2 \mathrm{~cm}) \\
\text { Kireç badana }(1 \mathrm{~cm})\end{array}$ \\
\hline
\end{tabular}

Simulasyon için oluşturulan modelde, duvar döşeme ve dam yapı elemanlarını oluşturan malzemeler ve bu malzemelere ait ısı iletkenlik katsayısı, özgül ısı ve birim hacim ağırlığı değerlerinin belirlenmesinde Ruhi Kafesçioğlu'nun "Çağdaş Yapı 
Malzemesi Toprak ve Alker" (2017) kitabında yer alan test sonuçlarından ve EnergyPlus programının kütüphanesinde yararlanılmıştır.

Tablo-2: Geleneksel düz toprak dam ve önerilen düz toprak dam için simülasyon sonucu belirlenen enerji matrisi

\begin{tabular}{|l|c|c|c|}
\hline & $\begin{array}{l}\mathrm{m}^{2} \text { başına tüketilen yılllk } \\
\text { enerji miktarı (kWh) }\end{array}$ & $\begin{array}{l}\text { Yıllık Isıtma enerjisi } \\
\text { gereksinimi (kWh) }\end{array}$ & $\begin{array}{l}\text { Yılllı soğutma enerjisi } \\
\text { gereksinimi (kWh) }\end{array}$ \\
\hline $\begin{array}{l}\text { Geleneksel Düz Toprak } \\
\text { Dam }\end{array}$ & 319 & 1392 & 10,77 \\
\hline $\begin{array}{l}\text { Önerilen Düz Toprak } \\
\text { Dam }\end{array}$ & 309 & 1350 & 10,23 \\
\hline
\end{tabular}

Simülasyon sonuçlarına göre oluşturulan Tablo-2'de görüldüğü üzere önerilen düz toprak dam detayı yaz ve kış aylarında, iç ve dış ortam arasında gerçekleşen ısı transferlerini azaltmaktadır. Buna göre önerilen düz toprak dam detayının uygulanması sonucunda geleneksel düz toprak dama göre yapıda tüketilmesi beklenen ısıtma enerjisinden $\% 3$ oranında; soğutma enerjisinden $\% 5$ oranında tasarruf sağlanmaktadır.

\section{Sonuç ve Öneriler}

Toprak gibi yerel ve ham malzemelerin kullanılmasıyla ortaya çıkan geleneksel kırsal mimari, doğal malzemelerin insan emeği ile şekillendirilmesinin sonucudur. Bu nedenle, toprak mimarisinin korunması yalnızca toprak yapıların korunması değil, aynı zamanda yapılı çevrenin belirli intiyaçlara uyarlanması için kullanılan geleneklerin ve insan becerilerinin temsiliyetinin de korunması olarak görülebilir.

Halen Anadolu kırsalında düz toprak dam uygulanan tek ya da iki katlı binalar mevcuttur. Ekolojik bir yapı malzemesi olan toprağın kullanıldığı düz toprak damların, Türkiye'de de yaygınlaşmaya başlayan ekolojik yerleşimlerde uygulandığı görülmektedir. Ancak bu uygulamaların kentsel alanda ve çok katlı binalarda uygulanması rasyonel değildir.

Çevre ve Şehircilik Bakanlığı, "Köy Evleri Projesi” ile farklı coğrafi bölgelere göre tasarlanmış tip ev projeleri geliştirmektedir (URL-2). Ancak, farklı coğrafi bölgeler için hazırlanan tip projelerde çatı çözümü için düz toprak dam elemanların henüz yer almadığı belirlenmiştir. Doğru çözümler ile detaylandırılacak düz toprak dam, kırsal mimari belleğin yitmemesi için önemli ve gereklidir. Bunun için Türkiye'de farklı toprak yapı üretim tekniklerini içeren, kapsamlı yasal düzenleme ve standartlara gereksinim olduğu ortaya çıkmaktadır.

Düz toprak damların sıkıştııı ış toprak katmanının, ısı yalıtım performansı azalmadan birim hacim ağırlığının dolayısıyla bina ölü yükünün azaltılmasına yönelik araştırmaların yapılması yararlı olur. 


\section{Kaynaklar}

Akbulut, Aydoğan, "Yazıcık (Niksar-Tokat/Türkiye) Bentonitleri: İlk Veriler", Türkiye Jeoloji Bülteni, Şubat 1995, Cilt 38, Sayı 1, 53-61

Anonim, TS 2515 Kerpiç Yapıların Yapım Kuralları, Ankara.1985.

Bulut Karaca, Ülger ve Şimşek Ergün, "Earth Roof in Anatolian Traditional Rural Architecture", VII. Internatıonal Virtual Architectural Design Conference Archdesign '20 Conference Proceedings, Ed: Özgür Öztürk, DAKAM Yayınları, April 2020, İstanbul

Büyükmıhçı, Gonca ve Salgın, Burcu ve Özkan, Aylin, "Yeşil Çatı Çözümlerinin Tarihi Dokularda Geleneksel Çatı Örtüsü Olarak Uygulanabilirliği Üzerine Bir İnceleme", Erciyes Üniversitesi Fen Bilimleri Enstitüsü Dergisi, Mayıs 2015, 31(2): 163-171

Çağlayan Murat, "Kırsal Mimarlığın Korunması İle İlgili Uluslararası Çabalar, Tüzükler", IV. Uluslararası Kültür Ve Medeniyet Kongresi, Ed: Doç. Dr. Bülent Cercis Tanrıtanır, Amenah Manafidizaji, Mardin 2018, s.273-279.

Anadolu'da Kırsal Mimarlık, 1. B., ÇEKÜL Vakfı Yayınları, İstanbul 2012.

Çiçek, Burhan, "Çağdaş Bir Yapı Malzemesi Olarak Toprak", Selçuk Üniversitesi Mimarlık Fakültesi-Konya "Sürdürülebilir Mimari Tasarımda Kerpiç Malzeme Kullanımı" Paneli / 16-18 Mayıs 2014 www.toprakyapilar.com/wp-content/uploads/2014/08/KonyaMakale.pdf (Erişim: 28.11.2020; 12:10)

Eres Zeynep, “Türkiye'de Geleneksel Köy Mimarisini Koruma Olasılıkları”, Ege Mimarlık Ocak 2016, 8-13

Kafesçioğlu, Ruhi, Orta Anadolu'da Köy Evlerinin Yapısı, 1. B., İstanbul Matbaacılık T.A.O., İstanbul 1949.

Kafesçioğlu, Ruhi, Çağdaş Yapı Malzemesi Toprak ve Alker, 1. B., ITÜ Vakfı Yayınları, İstanbul 2017

Koç, Zehra Gülşah ve Ekşi Akbulut, Dilek, "Ekolojik Tasarım Kapsamında Dünyada ve Türkiye'de Toprak Yapı Standart ve Yönetmeliklerinin Değerlendirilmesi", Megaron 2017;12(4):647-657 DOI: 10.5505/megaron.2017.48615

Koçu Nazım, "Sürdürülebilir Malzeme Bağlamında Kerpiç ve Çatı- Cephe Uygulamaları (Konya-Çavuş Kasabası Örneği)" 6. Ulusal Çatı \& Cephe Sempozyumu 12 - 13 Nisan 2012 Uludağ Üniversitesi Mühendislik ve Mimarlık Fakültesi - Görükle Kampüsü Bursa

Minke, Gernot, Building with Earth: Design and Technology of Sustainable Architecture, 1st Edition, Birkhäuser, Basel-Berlin-Boston 2009.

Muşkara Üftade, "Kırsal Ölçekte Geleneksel Konut Mimarisinin Korunması: Özgünlük”, SEFAD, 2017 (37): 437-448 
Özdoğan Mehmet. Kulübeden Konuta: Mimarlıkta IIlkler, Tarihten Günümüze Anadolu'da Konut ve Yerleşme, Ed: Yıldız Sey, Tarih Vakfı Yayınları, sayfa 19-29, 1996, İstanbul.

Özdoğan Mehmet, "Yeni Veriler Işığında Anadolu Mimarisinin Dünya Mimarisine Katkıları", Geçmişten Geleceğe Anadolu'da Malzeme ve Mimarlık Sempozyum / UIA 2005 XXII. Dünya Mimarlık Kongresi, Ed: Fehiman Yurttaş, TMMOB Mimarlar Odası İstanbul Büyükkent Şubesi Yayınları, İTÜ Taşkışla İstanbul, 2005 s.145-162.

Reyhanoğlu Gönül ve Yavuz Melek., "Işslevsel Bakış Açısıyla Kilis’te Dam Kültürü", Motif Akademi Halkbilimi Dergisi, 2020, Cilt: 13, Sayı: 31, 1118-1140.

URL-1: $\quad$ https://www.aa.com.tr/tr/turkiye/yoresel-mimariye-uygun-konut-insa-edeneucretsiz-proje-destegi-/1768735 (Erişim tarihi 02.12.2020, 13:00)

URL-2 https://www.altensis.com/hizmetler/designbuilder-software/ (Erişim tarihi 11.01.2021, 11:10) 